\title{
O CURSO DE CIÊNCIAS SOCIAIS TAMBÉM É COMO UM LAGO
}

\author{
Edmilson Lopes Júnior \\ Docente do Departamento de Ciências Sociais da \\ Universidade Estadual de Londrina
}

\section{Resumo}

Este artigo é uma contribuição ao debate sobre a reforma curricular dos cursos de Ciências Sociais no Brasil. Tomando como referência a metáfora do lago, utilizada por Charles Tilly para pensar a formação de uma cultura democrática, procuramos pensar os diversos elementos constitutivos de uma nova prática acadêmica nas Ciências Sociais.

Palarras-Chave: Currículo; Prática Pedagógica; Ciências Sociais no Brasil; Projeto de Curso.

presente texto, uma contribuição ao debate sobre a reforma curricular dos cursos de Ciências Sociais, toma como referência um provocativo artigo de Charles Tilly sobre a formação de uma cultura democrática (Democracy as lake). Nesse artigo, ao discutir as condições e o contexto necessários para a formação democrática, Tilly (2000) propõe que se tome o lago como uma metáfora para se pensar a construção da democracia. A sua proposição, em resposta a também metafórica definição de Barrington Moore de que a democracia seria formada similarmente a uma "jazida de petróleo", é a de que a democracia expressaria um processo evolutivo que lembraria um lago: "embora tenha propriedades distintivas e uma lógica própria, se forma em uma variedade de maneiras, cada um das quais retendo traços de sua história singular nos detalhes de seu funcionamento presente".

O lago, que podemos comumente definir como uma grande quanticlade de água represada numa área continental, após a sua formação (que se deve a fatores tão amplos quanto a queda de meteoros ou a 
construção de barragens), faz emergir "ecossistemas característicos que mantêm relações singulares com os seus arredores" (TILLY, 2000). Apropriadamente percebidos como ecossistemas complexos, os lagos se tornaram objeto de investigação científica de um campo multidisciplinar específico, a limnologia, que envolve saberes e práticas oriundos da botânica, zoologia e geologia, dentre outras disciplinas. A idéia central que tento defender é a de que, assim como ao estudo dos processos de construção da democracia, também à incursão sobre a estrutura curricular de um curso de Ciências Sociais na atualidade a limnologia fornece uma importante lição: a de que essa deve ser uma abordagem disciplinarmente descentrada. Guio-me pela hipótese de que ao se encarar o curso de Ciências Sociais metaforicamente como um lago e a discussão de sua reestruturação curricular como uma tarefa que ultrapassa as fronteiras das tradicionais disciplinas que o curso incorpora (antropologia, ciência política e sociologia), pode-se contribuir para uma redefinição positiva de toda a estrutura do curso, tornando-a apta a enfrentar a tarefa de produzir narrativas convincentes e socialmente legitimadas sobre a vida social no início do terceiro milênio.

Nos apontamentos abaixo, oriento-me por essa compreensão "lacustre" e embora tome a situação específica da graduação ofertada pela UEL como referência norteadora, faço considerações generalizantes com a pretensão de, modestamente, contribuir para os debates sobre a reforma curricular dos cursos de Ciências Sociais que estão ocorrendo em diversas universidades do país. Em verdade, apenas aponto algumas trilhas e atalhos para a construção de um currículo de um curso de graduação em Ciências Sociais no início do século XXI, num contexto educacional marcado pelas reformas de estruturas e instituições que até ontem eram tomadas como referências para se analisar a educação brasileira.

\section{O currículo não é um produto de engenharia social}

Comumente encarado como a tradução do projeto político e pedagógico de um curso, o currículo também pode ser apreendido como um texto aberto, com possibilidades múltiplas de elaborações de significados. Projeto político e produto cultural, o currículo é algo maior do 
que a estruturação de uma grade de disciplinas e um conjunto de atividades em torno de objetivos estabelecidos no planejamento educacional por um conjunto reduzido de atores. É um processo em construção, que embora constrangido pelos contornos da instituição na qual situa-se o curso, não se rende aos limites e à intencionalidade de seus atores. A experiência universitária na área das humanidades tem demonstrado que é exatamente no grau de imprevisibilidade que reside a riqueza e a complexidade do currículo num curso universitário.

Sempre maior do que os projetos e intenções racionalmente elaboradas pelos atores do curso, o currículo expressa-se em uma cultura acadêmica que é a conjugação de elaborações, visões e percepções construíclas em diferentes níveis e arenas do curso (das salas de aulas às reuniões departamentais). Nessas arenas desenvolve-se tanto o processo de legitimação do capital simbólico dos professores, quanto as lutas de resistências dos estudantes para que os códigos e valores produzidos pelas redes de sociabilidade nas quais estão inseridos não sejam totalmente descartados pelo ambiente acadêmico.

Como exercício de planejamento e colonização do futuro que é, o cuxículo, por mais consensual que seja a confecção da grade de disciplinas com a qual é geralmente confundido, não deixa de ser um espaço simbólico, marcado por escolhas e exclusões, muitas delas pouco conscientes. Assim, o currículo incorpora habitus e esquemas de percepção do mundo (BOURDIEU, 1989), implicando sempre a aceitação irrefletida de um amplo conjunto de pressuposições. No caso da graduação em Ciências Sociais, essa situação se expressa, por exemplo, em elaborações pouco aprofundas sobre o que seria a "formação ideal" a ser "fornecida" pelo curso. Não é raro que, após algumas rápidas declarações de intenções sobre esse tópico da pauta de debates da reforma curricular, se passe imediatamente a uma discussão pragmática sobre quais temas e autores estariam contidos na grade do curso para garantir a formação idealizada. Imediatamente, erguem-se vozes em defesa de uma "sólida" formação, alicerçada em um amplo domínio dos "clássicos".

Ora, não apenas a definição do que é "clássico" em Ciências Sociais não está fora de uma acirrada disputa teórica e política quanto o peso que o estudo dos clássicos deve ter em um curso de Ciências Sociais na atualidade é algo que não deve estar isento de fortes questionamentos. 
Retomaremos essa discussão mais adiante. Importa ressaltar, entretanto, a apreensão de que um currículo de um curso de graduação, especialmente na área de humanas, é o resultado de um equilíbrio de forças precário. Uma das consequiências possíveis dessa constatação pode vir a ser a proposição de que a discussão sobre a reforma curricular deva multiplicar os espaços de interlocução propositiva entre os atores do curso (alunos, professores, coordenador, chefe de departamento, docentes de outros departamentos que lecionam no curso, etc.).

Em outras palavras, trata-se de entender que uma reforma curricular não é uma tarefa técnico-burocrática, cuja resolução ótima dependeria do grau de eficiência e da competência em engenharia social dos seus condutores. Momento de discussão sobre os fundamentos mesmos do curso, a reforma curricular não pode deixar de propiciar também um conhecimento aprofundado sobre quem faz realmente o curso. E aqui se coloca, para os docentes, a necessidade de apreensão desse "outro" que é o nosso estudante.

Isso porque a reforma curricular dificilmente avançará em alterações substanciais na vida do curso se não possibilita a emergência de sujeitos, se não "autoriza" vozes e legitima "lugares de fala". Para ser eficaz, essa reforma tem, portanto, que ser democrática; o que, no meu entendimento, significa estar alicerçada numa "emocionalidade cooperativa" (FRANCO, 2001) entre os diversos professores e alunos do curso. Assim compreendida, a reforma curricular cria condições para que 0 mundo dos educandos possa emergir, tornando mais concreta a percepção dos docentes sobre esse ser que pretendem "formar". Essa digressão seria desnecessária caso não teimássemos em esquecer que é impossível a efetivação de um processo pedagógico sem o (re) conhecimento entre educadores e educandos.

\section{Tristeza e cansaço nos cursos de Ciências Sociais}

A tarefa de atribuir sentido ao mundo do presente é um dos principais elementos sobre os quais assenta-se a legitimidade social das Ciências Sociais. Entretanto, se é da "capacidade de interpelar o presente" (REIS, 1999, p.7) que depende a sua relevância, então, 
encontramo-nos, nas Ciências Sociais brasileiras, em um momento paradoxal. Mesmo que ainda consigam uma razoável audiência, através de uma estreita relação com os modernos meios de comunicação do país, os profissionais das Ciências Sociais brasileiras não têm transformado o capital cultural acumulado por essa sua exposição pública em aumento da legitimidade das próprias Ciências Sociais. Embora se deva fazer a ressalva de que os nossos intelectuais midiáticos têm sido sempre mais "legisladores" do que "intérpretes" da vida social, no que, diga-se de passagem, são fiéis tributários de nossa cultura bacharelesca tradicional'. O que importa registrar é que esse borboletear sociológico pode até possibilitar a alguns autores/atores os seus cobiçados "quinze minutos de fama", mas não diminui a tristeza e o cansaço que, intramuros, começa a dominar as paisagens de nossos cursos de Ciências Sociais.

O diagnóstico desse ambiente de tristeza foi feito pelo professor Hector Ricardo Leis, tomando como referência um contraponto com um momento de "festa" que teria predominado, especialmente na sociologia, nas décadas de 60 e 70 . Mesmo fazendo referência aos elementos contextuais (crise da universidade pública, ambiente cultural, experiências juvenis no terceiro milênio, etc), Leis (2000) nos convida a uma mirada na tristeza sociológica numa análise centrada em elementos tanto endógenos quanto exógenos. "Defeitos" como o moralismo e o reducionismo, aliados a uma progressiva perda da irreverência e da capacidade transgressora, estariam levando as Ciências Sociais (e, muito particularmente, a sociologia) a uma perda de audiência entre as melhores cabeças das novas gerações. Entretanto, para Leis (2000), tais manifestações não estariam relacionadas exclusivamente ao contexto acadêmico brasileiro. O normativismo e o reducionismo contaminariam as cabeças mais aureoladas das Ciências Sociais e incluiriam "entidades" como Anthony Giddens e Jürgen Habermas.

Nessa interpretação, teríamos quase todos esquecidos da grande lição deixada pela obra desenvolvida por Maquiavel: a separação entre

1 O estudo dessa cultura é uma tarefa decisiva para desvelar os entraves e as possibilidades das ciências sociais no Brasil contemporâneo. Ver, dentre outros, Adorno (1988) e Rezende (1998). 
ciência e moral ${ }^{2}$. Embora seja convincente a argumentação desenvolvida por Leis, apresento uma outra interpretação, menos distinta e muito mais complementar: se o moralismo, traduzido na necessidade de apresentação da "boa sociedade", é uma das fontes da tristeza da sociologia (e, eu acrescentaria, das Ciências Sociais em geral), a sua raiz está menos vinculada ao contrabando da ação social em ação moral (porto de onde saem os alegóricos barcos das bandas das Ciências Sociais normativas) do que em uma certa arrogância epistêmica que transforma os chamados pela interdisciplinaridade em exercícios retóricos e manifestações rituais (muito apreciadas, diga-se de passagem, pelas agências de fomento).

Essa arrogância epistêmica, forte em todas as Ciências Sociais, mas explícita na sociologia, apresenta-se como uma cabeça de Janus, em que uma das faces tem os traços do "imperialismo disciplinar" e a outra, as do "paroquialismo disciplinar". Andrew Sawyer, em instigante paper, define esses dois obstáculos à construção de campos transdisciplinares de investigação social:

"As disciplinas são paroquiais quando elas são incapazes de ver além das questões colocadas por sua própria disciplina, e através do filtro disciplinar abordam quase tudo. Onde a identidade e as fronteiras de uma disciplina são fortemente assinaladas e policiadas, abafa-se o avanço das descobertas e a inovação intelectual. (....) As disciplinas são também, algumas vezes, imperialistas. Isso ocorre quando elas tentam reivindicar territórios ocupados por outras disciplinas como sendo seus. Um exemplo bem conhecido é aquele da teoria econômica da public choice que tem reivindicado a habilidade e competência para tratar de temáticas como políticas e divisão doméstica do trabalho. O imperialismo disciplinar é estreitamente relacionado

2 Essa lição, que sobressai nas análises mais sofisticadas da obra do pai-fundador da ciência política moderna, deve ser constantemente relembrada. É isso que faz. por exemplo, Raquel Kristsh com a sua apresentação de $O$ Príncipe: “...além de ter uma finalidade prática, é uma obra que pretende ser um pequeno tratado sobre as condições de aquisição e manutenção do poder num principado. Pode-se dizer que é um texto de natureza teórica, pois ao falar da ação dos príncipes Maquiavel trabalha com uma tipologia de governantes, que de alguma forma está acoplada a uma tipologia de Estados. E. embora essas lições estejam particularmente voltadas para o caso dos principados, elas podem ser estendidas para outras formas de governo e de Estados" (KRISTCH, 2001, p. 182). 
ao paroquialismo disciplinar porque ambos têm dificuldade em pensar para além da estrutura de uma disciplina singular" (SAWYER, 2000).

Essas posturas são manifestações melancólicas porque expressões de resistência e lamento diante da erosão de um modo de conceber o mundo social que não mais consegue produzir narrativas consistentes e sedutoras. As disciplinas científicas, particularmente nas Ciências Sociais, são produtos históricos recentes. Tiveram peso e ajudaram a compreender o mundo, mas estão se tornando velozmente obsoletas. Vivemos um momento que é o do crepúsculo das disciplinas.

No Brasil, em que pese a renovação crescente dos quadros atuantes nas Ciências Sociais e a emergência de instituições fortes no campo, com a proliferação de cursos de pós-graduações e a publicação de revistas especializadas, o crepúsculo das disciplinas não parece motivo para comemorações. Pelo contrário! Entretanto, dada a estrutura de nossos cursos de graduação (e de muitos cursos de mestrado), que são de Ciências Sociais, ao invés de cursos de sociologia, antropologia e ciência política como acontece em outros países, poderíamos estar um passo à frente na articulação de experiências de ensino e pesquisa interdisciplinares. Não é, infelizmente, o que ocorre.

O caminho tem sido outro. No mundo real, impera o "paroquialismo disciplinar" nas outrora alegres Ciências Sociais brasileiras. As ousadas aventuras intelectuais de Gilberto Freyre e Florestan Fernandes, que romperam barreiras disciplinares e instituíram narrativas que foram além do mimetismo do olhar sociológico colonizado, têm cada vez menos admiradores. Expressão dessa realidade são os nossos babélicos encontros científicos. Verdadeiros happenings onde produções bem comportadas, generosamente financiadas pelos fundos públicos, são apresentadas para os iniciados de cada campo temático específico, não expressam maiores preocupações com interlocuções transversais. A presença nesses espaços, na realidade, alimenta menos a discussão teórica substantiva do que os investimentos com vistas à acumulação de capital cultural para a disputa de algum lugar "ao sol" no campo minado das Ciências Sociais brasileiras. Não se deve fazer marola nesses lagos tranqüilos. A não ser aquelas convenientes para a produção de resenhas amigáveis em despojados segundos cadernos dos grandes jornais. 
Correndo por fora, embora imersos na mesma arrogância epistêmica, encontramos os "legisladores" a quem já nos referimos. Alguns desses fazem "panfletagem Phd" (FIÚZA, 2001), são experts em análises pseudo-críticas sobre a "realidade política e econômica", não raro manejando com indisfarçável maniqueísmo dados estatísticos, acenando sempre para os cenários imediatos mais negativos. Como têm lugar cativo nos meios de comunicação, acumulam capital e conquistam audiências nas quermesses proto-acadêmicas dos que confundem ciência social crítica com elaboração teórica anticapitalista.

Outros personagens deslizam, em performances secundárias, nos cenários crepusculares das Ciências Sociais brasileiras deste início de milênio. Dentre esses, destacam-se alguns professores que se autoconstroem como os guardiões do Santo Graal. Suas aulas e trabalhos acadêmicos expressam a adesão às "verdades formulares" das grandes narrativas. Atuam como os últimos guardiões do cálice sagrado e imaginam-se do tamanho das temáticas grandiosas que pensam "dominar". Atormentados, aferram-se a lógicas e entidades abstratas atribuindo-lhes ações e potencialidades de atores concretos. Faça-se justiça: produzem pérolas memoráveis, embora literariamente pobres, sobre o tal "neoliberalismo". Não é raro que repudiem com veemência todas as pesquisas sobre questões pontuais e substantivas do mundo dos vivos. Como a direção do mundo vai em sentido contrário às suas profecias teleológicas, tornam-se melancólicos nihilistas enrustidos e, algumas vezes, levados pela necessidade de audiência, também praticam a "panfletagem Phd". As pessoas mais sérias e rigorosas das novas gerações encontram muito pouco sentido nos seus discursos e, intuitivamente, rejeitam suas receitas para "pensar o mundo".

Nem tudo é cinza, no entanto. Temos boas sínteses teóricas. E investigações sofisticadas, ancoradas em produções teóricas de ponta, que dão respostas consistentes à problemas concretos da sociedade brasileira já constituem um acúmulo de grande monta, apontando a competência das gerações que conquistaram destaque na nossa vida acadêmica nas décadas de 80 e $90^{3}$. Geralmente desenvolvidos por pessoas das novas gerações, esses trabalhos ainda não produzem impactos mais significativos no

\footnotetext{
${ }^{3}$ Um apanhado dessa produção foi feito por Sérgio Miceli (1999a. 1999b e 1999c).
} 
conjunto das Ciências Sociais brasileiras e, no que nos interessa mais de perto, nos cursos de graduação. Em parte porque a triagem disciplinar e a estrutura curricular arcaica desses cursos impedem a disseminação dessa nova forma de dar sentido ao mundo. Entretanto, suas produções se constituem em um acervo importante para aqueles cursos que queiram ir além das desestimulantes reapresentações dos mesmos temas e autores.

Ajunte-se a essa base, as experiências de intervenção, projetos de ensino e extensão que procuram criar espaços para novas formas de percepção e de problematização do mundo social, e teremos uma plataforma mínima para começar a elaborar as cartografias futuras de um currículo para um curso de Ciências Sociais. Nesse sentido, o Laboratório de Ensino de Sociologia da UEL é uma iniciativa que deve ser ressaltada e socializada com outras IES. No interior dessa experiência, a prática de ensino tem suscitado reflexões e produções acadêmicas que, relacionando-se criticamente com os clássicos das Ciências Sociais, apontam caminhos para uma abordagem didática de temáticas contemporâneas. Esse o caso, por exemplo, da proposição de Lenardão (2000) sobre o trabalho no ensino médio com a questão da violência.

É óbvio que esse cenário de tristeza está relacionado com as transformações estruturais da vida social contemporânea. As redefinições do lugar da ciência na sociedade atual (com a sua "dessacralização") e a erosão da figura do "intelectual missionário", ajuntam mais sombras no ambiente crepuscular anteriormente referido. Mas se obstáculos nos foram interpostos, possibilidades também foram abertas. $O$ desejo de entender a sociedade em que vivemos não se tornou menos forte com a aceleração do processo de globalização. Esse desejo pode se constituir num combustível para a renovação tanto dos cursos de graduação, como das práticas de ensino, pesquisa e extensão nas Ciências Sociais brasileiras.

\section{O lugar da licenciatura no curso e Ciências Sociais}

A reforma curricular do curso de Ciências Sociais na UEL não pode contornar a elaboração de uma resposta consistente sobre qual o sentido e o lugar da licenciatura no seu projeto pedagógico. Não são 
apenas os pareceres do CNE e a decisão do Presidente Fernando Henrique Cardoso de vetar a obrigatoriedade da filosofia e da sociologia no ensino médio que devem informar as discussões sobre essa temática delicada. Embora a discussão a ser realizada tome como referência esses vetores colocados em cena por fatores políticos mais amplos (relacionados às reformas na educação realizadas nos últimos anos), as questões mais consistentes e que podem potencializar uma reforma curricular calcada numa rica discussão dizem respeito a temáticas sempre relegadas ao segundo plano nos cursos de graduação em Ciências Sociais: como o curso de licenciatura relaciona-se com o ensino básico? que concepções de ensino básico informam os componentes curriculares da licenciatura em Ciências Sociais? quais as especificidades da formação para o ensino em Ciências Sociais? como estabelecer um aproveitamento mais racional dos recursos humanos e materiais partilhados pelos corpos discentes do bacharelado e da licenciatura?

As questões acima se desdobram em outras ainda mais substantivas: qual o sentido da manutenção de um curso de licenciatura diante da configuração que tem assumido o ensino básico no país? as pessoas e instituições comprometidas com a ampliação da legitimidade das Ciências Sociais no país devem investir tempo e recursos na formação de licenciados?

Duvido que alguém, individualmente, tenha respostas para as questões apontadas acima. Entretanto, o aprofundamento dessas questões é uma tarefa importante a ser realizada nos cursos de graduação em Ciências Sociais, como o da UEL, em que a licenciatura ainda cumpre um papel de destaque na atração de alunos. E, na medida em que a reforma curricular aqui discutida tem como espaço institucional fundamental o Departamento de Ciências Sociais, as questões apontadas terminarão por exigir dessa estrutura acadêmica, responsável pelas disciplinas da área em todo o âmbito da IES, a elaboração de uma justificação teórica e política minimamente consistente do que exatamente oferta-se aos distintos "clientes" de cursos tão diversos como medicina, direito, turismo e farmácia, dentre outros.

Essa é uma discussão da qual um Departamento de Ciências Sociais não pode fugir. Não se pode confundi-la, entretanto, com a defesa corporativa da manutenção da oferta de disciplinas do Departa- 
mento nos diversos cursos. Trata-se, sim, de inseri-la numa tarefa maior que é a de construir uma argumentação que justifique a introdução, permanência ou, dependendo do caso, ampliação das disciplinas da área de Ciências Sociais nos diversos cursos de graduação da Universidade. Afinal, do trabalho desenvolvido pelos docentes do Departamento em cursos tão afastados do nosso campo disciplinar quanto enfermagem contribui, mesmo que modestamente, para a legitimidade do fazer Ciências Sociais na universidade contemporânea.

Assim, pode ser que, ao se analisar o quadro interno da oferta de disciplinas da IES, tome-se como elemento definidor da política institucional de um determinado Departamento de Ciências Sociais a presença forte de nosso campo disciplinar num conjunto delimitado de cursos, além da concentração de esforços na oferta de um curso de bacharelado e de cursos de pós-graduação que levem à consolidação do ensino, pesquisa e extensão em Ciências Sociais. Em outras palavras, a oferta da licenciatura não pode ser encarada como uma obrigação formal do Departamento de Ciências Sociais, mas deve ser vista como una intervenção social e pedagógica que necessita ser precedida tanto de uma análise do contexto social em que está inserida a IES quanto de sua estreita vinculação com o projeto político e pedagógico do referido Departamento.

Não pode mais interessar às pessoas responsáveis pelos cursos de ciências sociais no Brasil uma situação em que a oferta da licenciatura seja algo que beira os limites do continuísmo irrefletido. Já que sempre ofertamos licenciatura e sempre existem candidatos para as vagas abertas nos vestibulares (particularmente nas IESs públicas), que se mantenha a licenciatura. Alheios ao que ocorre no mundo das práticas educacionais no ensino básico, tornamo-nos prisioneiros, também no que diz respeito a esta questão, de esquemas de percepção do mundo que podem até ter tido validade há duas ou três décadas, mas que tornaram-se completamente obsoletos numa sociedade que é, cada vez mais, "pós-tradicional” (GIDDENS, 1993). Num mundo em que predomina a "confiança ativa", baseada na justificação permanente das ações e proposições de indivíduos e relações, não existe muito lugar para a manutenção de ofertas de bens e serviços com base na tradição. 
Não é raro que a licenciatura seja tratada, no seio dos Departamentos de Ciências Sociais, como uma atividade menor, mera complementação pedagógica da formação básica fornecida indistintamente a bacharelandos e licenciados. Inexistem, com raras e honrosas exceções, espaços e momentos de discussões acadêmicas sobre as especificidades do ensino em Ciências Sociais. Obviamente, parte dessa situação está relacionada com o contínuo esvaziamento dos conteúdos humanísticos do ensino básico, ensejado pelas políticas educacionais das últimas décadas. Entretanto, o elitismo alienado dos que fazem Ciências Sociais no país também não contribui muito para superar essa situação. O dramático quadro da oferta de materiais didáticos de qualidade em Ciências Sociais é, a esse respeito, exemplar. Ao contrário da situação de outros países, no Brasil o campo profissional da produção de material didático ${ }^{4}$ em sociologia, antropologia e ciência política, é muito pouco explorado pelos pesquisadores de ponta ${ }^{5}$.

O licenciado em Ciências Sociais não enfrenta apenas o desafio de conseguir espaços de atuação no ensino básico, algo que, com raras exceções, é cada vez mais difícil, mas também os obstáculos advindos de uma formação que não the possibilita o enfrentamento de uma sala no instável e precário mundo do ensino médio brasileiro da atualidade. Nesse sentido, as indagações que mobilizam uma investigação empreendida pelos professores Lucinéa Aparecida de Rezende e Ronaldo Baltar, num projeto ainda em desenvolvimento sobre o ensino de sociologia, podem ser tomadas como questões orientadoras da discussão sobre a pertinência da licenciatura nos atuais processos de reforma curricular dos cursos de Ciências Socais: "qual a relevância desta disciplina (sociologia) em cursos de nível médio ou fundamental? Quais os conteúdos que preenchem as expectativas formuladas pela relevância atribuída à discipli-

\footnotetext{
+ O trabalho desenvolvido pelo professor Nelson Dácio Tomazi (1997) tem sido uma saudável exceção nesse campo. A sua dedicação à produção de material de apoio ao ensino de sociologia no nível médio tem se traduzido em materiais de boa qualidade.

s Exatamente o oposto do que ocorre em países como a Inglaterra. onde uma geógrafa como Doreen Massey, reconhecida como uma das mais importantes teóricas do campo da geografia, se dedicou a produzir un material didático que pode ser lido com facilidade pelos estudantes, mas que não deixa de abordar questões teóricas centrais. Vera respeito, Massey e Jess (1995).
} 
na? E qual é a fórmula capaz de tornar estes conteúdos inteligíveis para o público em idade escolar?" (REZENDE; BALTAR, 2000, p.150).

O diagnóstico preliminar esboçado por Rezende e Baltar (2000, p. 151) aponta para o fato de que, por questões relacionadas ao contexto em que se deu a re-inserção da sociologia no ensino médio, esta foi concebida como tendo relevância pelo "seu caráter de formadora de uma consciência de cidadania". Os autores reconhecem que os "bons quilos de livros sobre teoria sociológica, antropológica e de ciência política" pouco ajudam nessa tarefa heróica e, discordando dessa visão missionária, muito assumida pela defesa militante da obrigatoriedade da sociologia no ensino médio, esboçam um outro caminho para a presença das Ciências Sociais no ensino básico:

“...Não é papel das Ciências Sociais despertar consciência, mas sim explicar porque determinados fenômenos sociais ocorrem, qual a sua intensidade, como os indivíduos ou grupos são afetados ou os influenciam. Interessa saber porque as relações sociais acontecem de uma maneira e não de outra, e de que maneira isto afeta a organização ou a dinâmica da vida social. A pretensão deste tipo de conhecimento está em tornar evidentes os elos que ligam as biografias individuais à trajetória de um processo histórico. Dessa maneira, a relevância da Sociologia encontra-se na necessidade de oferecer métodos de raciocínio, explicações sobre modelos de interação social e análise de fenômenos sociais concretos que permitam, no contexto do sistema educacional como um todo, ser executada a tarefa de formar cidadãos" (REZENDE; BALTAR, 2000, p.152).

A preocupação com as questões pedagógicas relacionadas à introdução das Ciências Sociais (particularmente, da sociologia) no ensino básico, leva Rezende e Baltar (2000) a formular algumas proposições iniciais para dotar o curso de graduação em Ciências Sociais das condições necessárias à formação de um licenciado capaz de enfrentar o desafio de trabalhar numa escola no início do século XXI. Embora tomem como um dado a necessidade da oferta da sociologia no ensino médio, algo que, na nossa compreensão, requer maior discussão e fundamentação, esses professores apontam, implicitamente, o esgotamento do modelo tradicional de tratamento dispensado à licenciatura no 
meio acadêmico brasileiro. Esse modelo, que ergue uma "barreira" entre licenciatura e bacharelado, cristaliza-se numa divisão interna do trabalho baseada na suposta dimensão secundária da licenciatura. Propondo a superação dessa apartação, os autores afirmam que "a reflexão e o espírito investigativo estão na base do conhecimento das Ciências Sociais e não podem ser dissociados. Ensino e pesquisa em Ciências Sociais devem ser vistos como momentos de um mesmo processo de conhecimento, reflexão e explicação sobre os fenômenos sociais" (p.153).

A importância da licenciatura numa sociedade cada vez mais alicerçada no processamento de informações e na aprendizagem contínua, deveria ser, ao menos para o público acadêmico, algo tão óbvio que dispensaria maiores discussões. Não é bem assim no universo acadêmico brasileiro. Nesse sentido, é indiscutível a constatação abaixo, apresentada em um dos últimos pareceres do CNE sobre o formato a ser adotado pelos cursos de licenciatura no Brasil:

"As questões a serem enfrentadas na formação são históricas. No
caso da formação nos cursos de licenciatura, em seus moldes
tradicionais, a ênfase está contida na formação nos conteúdos da
área, onde o bacharelado surge como a opção natural que possibi-
litaria, como apêndice, também, o diploma de licenciado. Neste
sentido, nos cursos existentes, é a atuação do físico, do historia-
dor, do biólogo, por exemplo, que ganha importância, sendo que a
atuação destes como "licenciados" torna-se residual e é vista,
dentro dos muros da universidade, como "inferior", em meio à
complexidade dos conteúdos da "área", passando muito mais como
atividade "vocacional" ou que permitiria grande dose de improvi-
so e auto-formulação do "jeito de dar aula". (BRASIL, 2001).

Importa ressaltar que os pareceres exalados pelo CNE em 2001 sobre o imbróglio em torno das licenciaturas afirmam peremptoriamente que essas modalidades de cursos devem ter "identidade" e "terminalidade" próprias. Para se resguardar de remendos e mudanças de grades que não alteram substancialmente a estrutura curricular de cursos que ofertam tanto o bacharelado quanto a licenciatura, o CNE, no Parecer 28/2001 (BRASIL, 200lb), impôs uma carga horária com 800 horas de atividades práticas nos cursos de licenciatura. Essas atividades, estendidas a todo o período de execução do curso e não mais concentradas nos últimos 
anos, o que facilitava a oferta simultânea do bacharelado e da licenciatura, colocam novos desafios à reforma curricular em Ciências Sociais.

As modificações impostas pela legislação não são descabidas. Elas são, até certo ponto, uma resposta correta ao desarranjo estrutural de nossos cursos de licenciatura. Entretanto, essa situação, que exigirá um redimensionamento completo da forma de trabalhar na graduação em Ciências Sociais, implica um dispêndio considerável e, por isso mesmo, não é inoportuna a retomada da inquietante pergunta anteriormente colocada: vale a pena continuar oferecendo a modalidade da licenciatura nos cursos de Ciências Sociais?

A resposta a essa pergunta deve ser construída no seio de cada IES, levando em conta a trajetória histórica da oferta da licenciatura, a configuração atual ${ }^{6}$ e futura do corpo discente do curso, o ambiente educacional local e regional, além de considerações relativas à ampliação da legitimidade do curso de Ciências Social. Em unidades da federação em que a adaptação gerenciada pelas burocracias educacionais estaduais das políticas nacionais tem significado a eliminação da sociologia do ensino médio, a manutenção da licenciatura exige um redobrado trabalho de elaboração e justificação política de sua oferta.

Ora, um curso de licenciatura demandará, com a implementação das modificações preconizadas pelo Parecer CNE/CP 28/2001, uma dedicação maior do corpo discente. Não se trata apenas de um maior dispêndio de tempo, mas também de investimento emocional (algo fundamental para a atuação no ensino básico no Brasil do início do século XXI). O que significa ofertar um curso com tal carga de envolvimento pessoal com pouca ou nenhuma esperança de atuação do futuro profissional? Ora, ofertar um curso de licenciatura em Ciências Sociais, História, Filosofia ou Geografia não equivale a se oferecer cursos como Administração, Economia ou Turismo. No caso dos primeiros, um ambiente sóciocultural marcado pelo fechamento de fronteiras (ausência de possibilidades de transformação do longo tempo investido no estágio em atuação profissional) terá conseqüências desastrosas para a vida

\footnotetext{
- Um elemento importante, que por ironia é esquecido na discussão da reforma curricular, é o conhecimento sociológico sobre a re-configuração do corpo discente das IESs públicas brasileiras nas últimas décadas.
} 
acadêmica dos cursos. Desânimo, falta de participação, grande evasão e um baixo índice de conclusão são alguns dos efeitos de uma situação como essa. Algo que, no médio prazo, quando os cursos de Ciências Sociais forem incluídos no "Provão", pode se constituir num desastre que colocará em xeque o campo das Ciências Sociais como um todo.

No caso específico da UEL, levando em conta a história da oferta da licenciatura em Ciências Sociais e a existência de experiências como o Laboratório de Ensino de Sociologia, além da luta pela re-introdução da sociologia no ensino médio no Paraná, a oferta da licenciatura deve ser mantida. Para que isso aconteça, faz-se necessário, entretanto, que esse curso esteja alicerçado em um projeto político-pedagógico que the dê substância e identidade própria (com a criação, por exemplo, de fóruns específicos como o colegiado de curso). Assim compreendida, a licenciatura pode significar um revigoramento do curso de Ciências Sociais, na medida em que um projeto consistente de licenciatura voltado para a atividade de ensino numa sociedade moldada pelas estruturas de informação e comunicação (TI\&C) exige que o corpo docente matenha uma interlocução permanente com os repertórios culturais mobilizados pelos alunos, professores em formação. Essa interlocução não apenas amplia o universo de compreensão do mundo social, mas também abre a possibilidade de uma maior instrumentalização pedagógica de tecnologias e linguagens que, embora sejam de domínio dos estudantes, ainda são pouco utilizadas nas salas de aulas de nossas universidades.

\section{A reforma curricular e o encontro com 0 outro que nos desafia}

Podemos compreender um currículo também como uma cartografia sempre inacabada dos projetos, programas de ensino, repertórios culturais, interações face a face e narrativas construtoras de sentidos do mundo de todos os atores envolvidos com um determinado curso. Obviamente, essa intrincada cartografia é cruzada por culturas distintas, muitas delas "desencaixadas" do meio ambiente imediato de interação dos atores, como as culturas disciplinares presentes nos diversos corpos de saberes manejados no referido curso ou ainda os elementos 
culturais oriundos do "arranjo institucional" que possibilita a oferta e manutenção do curso. No que diz respeito ao input dos atores, a moldura do curso expressa não apenas o capital cultural acumulado nas trajetórias intelectuais dos seus docentes, mas também as percepções e repertórios mobilizados pelos estudantes.

Compreender as experiências pessoais e os repertórios culturais empregados pelos estudantes não significa escorregar num pervertido populismo acadêmico, mas realizar um exercício de análise sobre quem é esse "outro" com o qual nos relacionamos nas salas de aulas dos cursos de Ciências Sociais. Essa é uma tarefa indispensável para fornecer ao projeto político e pedagógico do curso que se pretende reformar algo mais do que um arrazoado de conteúdos programáticos encaixados numa grade curricular bem arrumada. A esse respeito, nunca é demais lembrar as lições deixadas pelos clássicos do pensamento educacional: se a ação pedagógica significa, em maior ou menor medida, a imposição de um "arbitrário cultural" (BOURDIEU, 1975), ela nunca é, no entanto, unidimensional e os educandos, mesmo nas mais fechadas instituições educacionais, sempre subvertem os scripts traçados alhures e ampliam as suas potencialidades enquanto sujeitos instituintes do social.

A juventude que adentra nossas salas de aulas vive, com uma radicalidade impensada há alguns anos, profundas transformações no que diz respeito às suas experiências pessoais, processos de individuação e socialização. Se a compreensão do universo jovem do século XXI é uma tarefa inadiável para qualquer educador, mais premente ainda é a incorporação desse desafio pelos que pretendem esboçar um projeto político e pedagógico para um curso de graduação na área das Humanidades. Sem isso, torna-se impossível a realização de qualquer análise prospectiva na redefinição do currículo. Refiro-me, particularmente, à elaboração/especulação sobre os cenários futuros do curso: perfil desejado do/a formando/a, expectativas quanto à contribuição do egresso em relação aos objetivos políticos assumidos pelo curso, articulação do curso ofertado com os projetos idealizados para a pesquisa e a pós-graduação pelo respectivo departamento acadêmico, etc.

Esse é um exercício que não se confunde com as pesquisas tradicionais sobre o perfil do corpo discente. O que estou propondo é uma verdadeira incursão nas cartografias da juventude contemporânea ${ }^{7}$, uma 
aventura intelectual menos preocupada em produzir respostas apressadas e mais disposta a um exercício que também é de auto-compreensão. Afinal, partilhamos da mesma atmosfera espiritual e estamos todos envolvidos pelos mesmos redemoinhos que redefinem não apenas as formas de socialização, mas as circunstâncias que delimitam a própria construção do self na contemporaneidade.

Assim, vale a pena questionar: qual o significado sociológico da experiência jovem na atualidade? quais as habilidades que diferenciam positivamente a geração atual das anteriores? quais as suas vulnerabilidades? qual o ambiente em que eles e elas desenvolvem as suas experiências? que conexões fazemos com o seu mundo? Muito embora a juventude, enquanto construção social que é, seja uma experiência temporal cada vez mais elástica nas sociedades contemporâneas, incorporando progressivamente os "eternos jovens" como Mick Jagger, ela é demarcadora de experiências e delimitadora de identidades que não podem ser de todo contornadas no exercício pedagógico.

Numa análise sobre o trote universitário como ritual de passagem, as professoras Kimiye Tomassini e Leila Sollberg Jeolás (2000, p.39) nos fornecem importantes pistas para pensar as questões acima mencionadas:

"com o processo crescente, desigual e complexo de urbanização e de industrialização, introduziram-se profundas mudanças nas instâncias da religião e da família, enfraqueceram-se, progressivamente, os laços de parentesco, as relações de vizinhança, as associações voluntárias, as festas de bairro e outras formas de sociabilidade e socialização. Paralelamente a esta ruptura, elaboram-se novas formas de sociabilidade para responder à necessidade de experiência comunitária..."

A preocupação com os processos de socialização numa sociedade em que as estruturas tradicionais são corroídas por processos de individualização cada vez menos encaixados localmente está presente nas mais relevantes abordagens das Ciências Sociais contemporâneas. Não vou aqui resenhar essas contribuições. Devo, entretanto, para fun-

\footnotetext{
${ }^{7}$ Nesse sentido, a existência, no Departamento de Ciências Sociais da UEL, de um grupo de estudos e pesquisas sobre a juventude significa um importante diferencial positivo que deve ser incorporado no processo de reformulação curricular.
} 
damentar argumentos que desenvolverei mais adiante, destacar alguns aspectos da instigante análise desenvolvida pelo sociólogo catalão Manuel Castells, em seu projeto de análise do tecido e das redes sociais na sociedade informacional. Para Castells, numa análise assumidamente estruturalista, a transformação das paisagens humanas contemporâneas traduz-se numa redefinição substantiva das nossas relações interpessoais, e especialmente das relações de gênero.

Seguindo de perto as proposições formuladas por Anthony Giddens, e apoiado numa sofisticada base de dados sobre o tamanho e a estrutura interna da família moderna, o casamento, as taxas demográficas, a presença feminina na força de trabalho, dentre outros fenômenos, Castells (1999b, p. 275) diagnostica:

"as novas gerações estão sendo socializadas fora do padrão tra-
dicional da família patriarcal e expostas, já na infância, à necessi-
dade de adaptarem-se a ambientes estranhos e aos diferentes pa-
péis exercidos pelos adultos. Em termos sociológicos, o novo
processo de socialização restringe de certo modo as normas
institucionais da família patriarcal e diversifica os papéis exercidos
pelos seus membros. (...) Como resultado desses processos, no-
vas personalidades vêm à tona, mais complexas, menos seguras
de si, porém mais capazes de adaptarem-se aos papéis em mudan-
ça constante dentro dos contextos sociais, uma vez que seus me-
canismos de adaptação são acionados desde a mais tenra idade"

Embora conceitos sociológicos como "papéis sociais", que têm como referência a dinâmica social da modernidade devam ser eles próprios colocados sob suspeitas num mundo em que, como diria o Nobre Próspero, o comentado personagem de Shakeaspeare em A tempestade, "tudo o que é sólido desmanchar no ar", as incursões sociológicas de Castells fornecem pistas de investigação que não devemos dispensar. Não se trata, por certo, de lamentar que as personalidades que emergem na sociedade informacional não se encaixem mais nas narrativas sociológicas totalizantes, mas de, apreendendo as suas singularidades, construirmos guias (desde que se tenha a humildade de reconhecer a limitação epistemológica destes) que nos possibilitem transitar nas novas paisagens sociais. Desde que estejamos dispostos, obviamente, a nos perder (e, só assim, nos encontrar) na labiríntica casa de espelhos das 
manifestações e espacializações sociais das polifônicas culturas jovens com as quais nos defrontamos (e na maioria das vezes, ignoramos) nas nossas próprias salas de aulas.

A indagação sobre as experiências sociais nas quais estão inseridos os jovens que frequientam nossos cursos na Universidade pode levar, como geralmente ocorre com os estudos do "outro", a uma autodescoberta de imagens e discursos irrefletidos que estruturam nossas identidades (como educadores e intelectuais, por exemplo). Somente assim poder-se-á superar as lamentações sobre a "despolitização", "alheamento" e "pobreza cultural" da juventude contemporânea. Superando a "congelação metonímica" (CLIFFORD, 1995, p.53) dos jovens como "outros", poderemos nos colocar o desafio de apreender os múltiplos repertórios culturais de que são portadores. Repertórios esses que são muito mais do que elementos constitutivos das suas identidades individuais e coletivas: são também sofisticadas chaves de interpretação do mundo no qual vivemos.

\section{O ensino de Ciências Sociais na sociedade informacional}

O processo educacional assume novos contornos em uma sociedade na qual a informação, como aponta-nos CASTELLS (1999a, p.265), ascende à condição de elemento decisivo da produção. Marco importante na interpretação das transformações sócio-econômicas impulsionadas pelo processo de globalização, o conceito de "sociedade informacional", formulado por Castells (1999a, p.51), procura dar conta dos cenários e processos sociais deste momento histórico em que a "mente humana é uma força direta, não apenas um elemento decisivo no sistema produtivo" e pode ser tomada como uma referência balizadora de nossas incursões no campo da educação.

Diga-se de passagem, a utilização do conceito de sociedade informacional feita por Manuel Castells vai muito além das incursões anteriores de Daniel Bell e Alain Touraine. Apesar de não superar a tentação das sínteses grandiosas e das generalizações universalizantes, Castells consegue elaborar um denso painel da vida social no presente 
sem escorregar nas armadilhas impostas pelo porto seguro de uma metalocalização. O autor da trilogia sobre "a era da informação" não se refugia num lugar seguro para vislumbrar as paisagens do presente, como o fazem, por exemplo, David Harvey ${ }^{8}$ e Frederic Jameson, que empreendem análises ambiciosas dos repertórios e das paisagens culturais contemporâneas a partir do "terreno seguro" fornecido pela base material (em ambos, o capitalismo flexível ou pós-fordista). Para Castells, e nesse aspecto sua análise cumpre um papel importante para todos os que estão preocupados com a produção de interpretações sobre o universo cultural (e, particularmente, a cultura pedagógica), a economia não é uma dimensão a partir da qual se possa ler todo o social nem algo dotado de lógica e posturas típicas de atores concretos, mas uma prática que não independe de representações e institui (e é instituída) pela cultura?.

De que modo o conceito de sociedade informacional e os cenários desenhados por Castells nos ajudam a pensar o desafio do ensino de Ciências Sociais? Na realidade, essa questão aponta para algo que é teimosamente excluído do âmbito de nossa reflexão nos processos de reforma curricular de nossos cursos: o que é o ensino num curso de Ciências Sociais no início do terceiro milênio? Essa é uma pergunta incômoda na medida em que obriga a uma reflexão sobre o que tem sido feito nesse ensino. Em outras palavras: como se dá, atualmente, o ensino no curso de Ciências Sociais? qual a compreensão de formação, de conteúdo de cada uma das áreas disciplinares e de didática que o nosso curso traduz? Como se dá o processo de comunicação entre docentes e estudantes no curso?

Se, como apontamos anteriormente, é fundamental o (re)conhecimento desse "outro" com o qual os professores se defrontam em sala de aula, igualmente importante será a apreensão dos novos con-

\footnotetext{
* Ver a respeito, Harvey (1993). Para uma crítica ao reducionismo economicista de David Harvey, ver Featherstone (1997, p.13-16).

"Manuel Castells, assim como Saskia Sassen (2000), faz parte de um conjunto cada vez maior de analistas sociais que assumem o desafio de elaborar grandes painéis analíticos sobre a economia. tomando as geniais intuições de Karl Polanyi em $A$ grande trunsformação como referência. E Polanyi (1980), como sabemos, nos legou a proposição polêmica (e analiticamente fértil) de que toda atividade econômica é culturalmente "embebida".
} 
textos que delimitam a relação entre educadores e educandos. A indagação sobre os processos de individualização e construção da personalidade numa era em que os meios de comunicação retiram as relações interpessoais do face a face imediato é, nesse sentido, imprescindível.

A idéia de que as novas "tecnologias de informação e comunicação" (TI\&C), na verdade, ampliam à enésima potência o processo de desencaixe das relações sociais destravado pela modernidade é esposada por um amplo conjunto de cientistas sociais. Entretanto, a redefinição causada pelas TI\&C nos processos de construção da personalidade foi analisada com perspicácia pelo sociólogo inglês John B. Thompson. Tomando como referência a proposição de Cliford Geertz sobre o "saber local", isto é, aquele tipo de conhecimento ancorado nas interações cotidianas face a face e adaptado para dar respostas às questões práticas da vida, Thompson $(2000$, p. 184) aponta para a situação atual na qual a formação do self está ligada a formas mediadas de interação Assim, "ao abrir novas formas de conhecimento não local e outros tipos de material simbólico não mediado, o desenvolvimento da mídia enriqueceu e acentuou a organização reflexiva do self" (p. 185).

Em que essa análise contribui para a reflexão sobre o processo de ensino e aprendizagem nas Ciências Sociais? Ela nos indica que devemos aprender a nos relacionar com pessoas cujas personalidades são moldadas por relações de intimidade com outras pessoas situadas em recônditos espaços, a maioria deles virtuais. E não estamos nos referindo apenas à interação via internet. Pensemos num dos mais expressivos fenômenos televisivos brasileiros dos últimos anos: a "Casa dos Artistas", o reality show que fez com que o SBT, nos meses de novembro e dezembro de 2001, desbancasse a liderança de audiência da TV Globo. Se refletirmos um pouco sobre o imaginário construído em torno da performance de um dos participantes do programa, o roqueiro Supla, poderemos chegar à conclusão de que a sua condição de "queridinho" dos telespectadores correspondeu a algo mais profundo do que a expressão da maniqueísta luta do "bem" contra o "mal" dos enredos tradicionais da teledramaturgia brasileira. Não me interessa aqui se o bom-mocismo do roqueiro era ou não premeditado. O que importa frisar é que a sua atuação foi lida pelo público como "autêntica" e, assim, Supla era o "cara legal", representante não do pólo do "bem" 
contra o do "mal", mas do "autêntico" contra o "mascarado". Supla era "legal" porque sendo "ele mesmo" possibilitava um tipo diferente, e em ascensão, de relação íntima da sociedade informacional: a "relação íntima não recíproca e à distância".

Evento midiático acompanhado pelos jovens de muito perto, "A casa dos Artistas" nos revelou que, ao contrário do que os analistas culturais mais simplistas costumam vociferar, a audiência televisiva está longe de ser passiva e é inconcebível sem a mobilização de um esquema de interpretação do mundo. $\mathrm{E}$, ao incorporarem e processarem reflexivamente as imagens e modelos fornecidos pela mídia à sua vida diária, as pessoas o fazem através de esquemas estreitamente vinculados a valores éticos. No caso, um valor ético importante dos tempos atuais, a autenticidade pessoal ${ }^{10}$, que se traduz no fato de que a vida pessoal passa a ser encarada, cada vez mais, como um projeto que é mais estético do que político.

A análise acima convida-nos a pensar sobre o fato de que, na medida em que a floresta de signos com a qual nos defrontamos na nossa sociedade se torna mais densa (diretamente proporcional à expansão vertiginosa das tecnologias de informação e comunicação) e se tornam concretas as possibilidades de que os indivíduos se percam nesse emaranhado de signos, não se pode negar que, muitas vezes, os indivíduos, intérpretes ativos que são, estruturam mapas cognitivos a partir dos bens culturais que consomem. $\mathrm{E}$ as pessoas que estão nas nossas salas de aulas (nas escolas e nas universidades) são parte desse expressivo contingente. Se essa constatação tem algum fundamento, então, devemos nos inquietar com a seguinte questão: como fazer com que o ensino de Ciências Sociais reforce esse potencial reflexivo que é o diferencial positivo dos jovens atuais em relação àqueles das gerações precedentes?

A irrupção constante do que alguns analistas denominam subculturas juvenis é uma das traduções desse potencial reflexivo da juventude atual. A antropóloga Leila Sollberg Jeolás, professora do Departamento de Ciências Sociais da UEL, relatou-me em conversa re-

${ }^{10}$ Essa situação corresponde a um sintoma mais amplo da sociedade atual: a "centralidade dos indivíduos em relação à instituição" (BARRERE; MARTUCCELLI, 2001, p.275). 
cente, a sua descoberta do universo do movimento hip-hop na cidade de Londrina. Há dois anos, esse movimento inexistia. Hoje, mobiliza grupos de jovens, bandas musicais, além de instituir novas formas de apropriação de bens culturais e abrir novos espaços de encontro (os locais de apresentação das bandas). Ao invés de pobreza e vazio cultural", a juventude que está sendo socializada no momento de radicalização do processo de globalização (e de afirmação da sociedade informacional) mobiliza um espectro cada vez mais amplo de instrumentos para interpretar e dar sentido ao mundo que the coube viver.

O ensino de Ciências Sociais, superando a monótona repetição das fórmulas de sempre, pode ser muito mais produtivo se conseguir potencializar essa capacidade de produção de novos recursos culturais da juventude atual. Essa é uma proposição que se apóia numa compreensão do universo cultural do presente, enfaticamente defendida pelos pesquisadores dos "estudos culturais", dentre eles Mike Featherstone. O diagnóstico de Featherstone (1997, p.154), diretor da revista Theory, Culture and Society, não pode ser mais desconcertante para os eternos nostálgicos do modelo explicativo implícito na noção de "indústria cultural":

"Experimentamos aqui a sensação de que o mundo contemporâneo não presenciou um empobrecimento cultural, uma atenuação dos recursos culturais. Tem havido, na verdade, uma ampliação dos repertórios e uma intensificação da engenhosidade de grupos no sentido de lutar para re-trabalhar e voltar a moldar o significado dos signos existentes, de solapar hierarquias simbólicas existentes, para seus próprios objetivos particulares, de modo que se torna difícil de ser ignorado por aqueles que se situam nos centros culturais dominantes."

A análise precedente pode ser tomada como referência para uma reorientação do ensino no curso de Ciências Sociais que poderia se traduzir nos seguintes tópicos:

"A proposição de que a globalização corresponderia a uma estandartização das paisagens culturais, ainda que encaixada em análises sofisticadas como aquela empreendida por Zuin (1998), deixa de perceber que mesmo o "mero" consumo de bens culturais "industrializados" implica a mobilização de esquemas de interpretação (e de saberes ancorados no contexto onde se situam os consumidores). além da produção de novas identidades pessoais e coletivas 
a) possibilitar um ambiente acadêmico em que, desde o momento de entrada no curso de graduação, o aluno seja estimulado a exercitar as suas potencialidades de intérprete do mundo social. O que significa priorizar a produção de discursos significativos sobre o mundo ao invés do simples consumo e repetição ad nauseam dos modelos consagrados de análise. Nesse sentido, o estímulo à escrita, através da produção de pequenos textos de análise sobre tópicos relacionados a cada disciplina do curso, cumpre um papel decisivo;

b) o ambiente do curso é um importante elemento do currículo (ou da dimensão "oculta" deste, diriam algumas pessoas) e, assim sendo, deve-se trabalhar pela criação de um clima de cooperação intelectual entre os professores (algo que não eliminaria as divergências no seio do corpo docente do curso, mas as tornariam mais produtivas) e entre os docentes e os estudantes;

c) trabalhar com a idéia de que uma boa formação corresponde não a uma maior ou menor incorporação desse ou daquele modelo de interpretação do mundo social, mas, simplesmente, a aquisição de uma "capacidade autônoma de conhecimento e de interpretação dos fatos" (KOUTSELINI, 1997; p.94).

d) a sociedade informacional, como sociedade destradicionalizada que é, ao possibilitar o acesso de leigos aos bancos de dados de conhecimentos especializados, dinamita a autoridade do saber douto e este não tem mais nenhum sentido. Entendo que uma sala de aula, especialmente num curso de Ciências Sociais, deve ser concebida, como um espaço onde predominam relações alimentadas pela "confiança ativa" (GIDDENS, 1993), isto é, pela disposição permanente dos professores em conquistar, pelas atitudes e argumentos, a confiança de seus alunos;

e) fazer com que alunos e professores incorporem progressivamente as novas TI\&C, não apenas tirando proveito dos ban$\cos$ de dados virtuais disponíveis, mas fomentando e subsidiando experiências inovadoras, como, por exemplo, a de criação de portais dedicados ao ensino de Ciências Sociais 
(no âmbito do DCS da UEL já se encontra em desenvolvimento um promissor projeto de montagem de um portal na internet, coordenado pelo professor Nelson Tomazzi);

f) por último, mas não o menos importante dos pontos que menciono, é inconcebível que, num curso de Ciências Sociais, a dimensão generificada da sala de aula deixe de ser problematizada. Isto é, docentes e discentes devem ser estimulados a pensar e levar em conta, na prática pedagógica, os limites impostos pelas relações de gênero nas interações que ocorrem em todo o espaço da vida acadêmica. Des-naturalizar o androcentrismo da prática pedagógica pode se traduzir, em primeiro lugar, num saudável exercício de auto-análise dos docentes (homens e mulheres) sobre até que ponto suas posturas em sala de aula naturalizam "aspectos" socialmente construídos do ser homem e ser mulher em nossa socieda$\mathrm{de}^{12}$. Essa postura significaria a incorporação de uma das précondições para a atividade de ensino numa sociedade destradicionalizada, na qual a autoridade e a confiança não são dadas, mas conquistadas, o que vem a ser exatamente o "tato pedagógico" (MANEN, 1995, p.40), isto é, uma sensibilidade para a inclusão (MANEN, 2002, p.217) como um dos principais elementos da prática educacional.

\section{As vertentes do lago}

Se o curso de Ciências Sociais pode ser tomado também como un lago, então, as suas águas advêm das mais diferentes vertentes. A partir dessa percepção, discuti, nos tópicos anteriores, a situação atual do curso no contexto mais amplo de autoconstrução das ciências brasileiras, apontando alguns dos elementos que caracterizam o seu complexo ecossistema. Não posso fugir, entretanto, da tarefa de apontar algumas direções que a conformação de uma nova estrutura curricular num curso de Ciências Soci-

\footnotetext{
12 Para uma instigante e sedutora análise do androcentrismo como o etnocentrismo dominante no mundo da educação, ver Moreno (1999).
} 
ais deveria ter. Projeções idealizadas, as indicações abaixo devem ser entendidas como vertentes que, incorporando muitas outras produzidas pelos diversos autores/atores do curso, podem fazer com que o esvaziado lago das Ciências Sociais volte a ter densidade e profundidade, possibilitando que o seu entorno ambiental volte a ser o espaço da curiosidade intelectual, da investigação substantiva e da festa do espírito crítico.

\section{a) o ser, o link e a aprendizagem reflexiva}

A idéia do curso de Ciências Sociais como um hipertexto, no qual os cursos e disciplinas apresentam-se como uma versátil leitura de temáticas, sempre possibilitando a conexão com múltiplos links, anteriormente apontada, tem sido objeto de conversas com colegas professores. Tratada com ironia ou encarada como coisa exótica, essa proposta seduz pouca gente no nosso meio. Dado que um dos subprodutos mais importantes de um processo de reforma curricular é exatamente a discussão aprofundada de todas as alternativas apontadas para enfrentar o esgotamento do modelo curricular que se quer alterar, talvez valha a pena perder alguns momentos com as proposições aparentemente mais descabidas.

A idéia de um curso concebido como um hipertexto procura enfrentar o maior problema de qualquer discussão de reforma curricular em Ciências Sociais: como garantir uma formação básica ao aluno? Quando se chega a discutir essa tal "formação básica", não é raro que as questões sejam quais os autores a serem tratados e quais disciplinas "auxiliares" merecem maior carga horária no curso. A discussão sobre o sentido mesmo da formação básica dificilmente é enfrentada. Caso se insista na pergunta, é comum que algum "reformador", com o bocejo dos que apontam o óbvio, afirme que a formação básica é o acesso aos "clássicos das Ciências Sociais" e dê por encerrada uma discussão que the parece enfadonha e desprovida de sentido.

Talvez os cursos de Ciências Sociais ganhassem mais (em consistência e em complexidade) caso enfrentassem com maior profundidade a discussão sobre o sentido da formação básica. Em primeiro lugar, não se pode temer uma questão: formação básica nos nossos cursos deve ser compreendida como equivalente ao domínio dos clássicos? Se assim o for, por que não nos questionarmos sobre o que significam os clássicos 
atualmente nas Ciências Sociais $?^{13}$ Não se deveria tratar com naturalidade essa discussão. Assim, não é extemporâneo questionar: qual o sentido de se passar dois anos fornecendo leituras dos "clássicos" aos alunos de Ciências Sociais? em que os clássicos contribuem para o exercício de conferir inteligibilidade aos processos sociais do mundo contemporâneo?

Não se trata aqui de retomar o velho debate entre "história" e "sistemática" na ciência social (em particular, na sociologia), proposto pelo funcionalismo americano da primeira metade do século XX, mas de saber: existe utilidade na leitura dos clássicos para os estudantes de Ciências Sociais do início do século XXI? Caso a resposta à questão anterior seja afirmativa, então, trata-se de enfrentar o desafio de apontar quais os caminhos para facilitar o acesso desses estudantes do século XXI aos clássicos.

Para evitar mal-entendidos, adianto que entendo que o acesso aos clássicos se justifica por razões pragmáticas e "funcionais". Isso porque os clássicos, na medida em que haja consenso sobre a sua estatura de "clássicos", se constituem em referentes que, em última instância, prestam-se a legitimar a autoridade discursiva no campo. Em nossas ciências, nas quais as evidências empíricas podem sempre ser sobrepujadas (ou descartadas) pela mobilização de arsenais discursivos, os clássicos também funcionam como conjuntos de enunciados referentes aos quais pode-se recorrer para facilitar a comunicação e a construção de significados.

Ora, se estamos todos de acordo com a proposição de que a legitimação de um conjunto determinado de autores como clássicos é o resultado de um processo de disputas políticas e teóricas, algo que sempre pode ser redefinido pelas últimas releituras, talvez devêssemos trabalhar não com a delimitação tradicional de "clássicos" (autores e obras), mas com a noção de "cânone das Ciências Sociais". Tomada de empréstimo do crítico literário norte-americano Harold Bloom, mas destituída das cargas estéticas elitistas com que ele a recobre, a noção de "cânone"|lt pode nos servir para delimitar um campo de temáticas, con-

1. Essa é uma discussão cujo aprofundamento foge aos objetivos deste texto. Uma importante referência para essa discussão nos é fornecida por Alexander (1999). 
textos, textos, autores, conexões literárias com os universos temáticos dos clássicos ${ }^{15}$, etc. Compreendido como uma imensa floresta de signos, esse "cânone das Ciências Sociais" se constituiria dos textos (e contextos de produção) dos clássicos, de suas controvertidas inserções em cada cultura disciplinar, de sua apropriação nos contextos culturais nacionais ${ }^{16}$, além das leituras e releituras dos diversos projetos de desconstrução.

Metaforicamente, poderíamos tomar esse "cânone" como um continente virtual ao qual levariam, ao longo de todo o curso, os links inseridos nos conteúdos programáticos de todas as disciplinas. Assim, ao invés de uma leitura cansativa e pouco produtiva de obras isoladas de alguns autores, teríamos uma aproximação pragmática do "cânone", baseada no tratamento de temáticas substantivas e, por que não?, sedutoras. Essa a forma de, enfrentando a obsolescência inevitável do ensino da jovem ciência social, tornar a nossa aprendizagem reflexiva, na medida em que a mesma conecta-se com as inquietações, anseios e angústias do ser (alunos e professores do curso).

\section{b) As Ciências Sociais e a percepção dos cães: a necessidade de um curso que possibilite o diálogo com outras linguagens e formas de interpretação do mundo}

Fruto de uma parceria dos cineastas Dorjkhandyn Turmunk e Peter Brosens, O Estado do Cão (Nohoi Oron de 1998) é um dos filmes mais elucidativos sobre os traumáticos processos sociais de transição para a economia de mercado vivido pelos países que antes

\footnotetext{
${ }^{4}$ Essa proposição é defendida, com o sentido de defender o projeto editorial de uma publicação acadêmica dedicada ao estudo dos clássicos, no editorial de lançamento da revista Joumal of Classical Sociology. Ver Introduction ...(2001).

15 Trata-se de, seguindo o magistral trabalho de Berman (1986), perceber a importância das obras literárias como chaves de interpretação das obras dos clássicos. O que significa que num curso de Introdução à Sociologia, a leitura de Charles Dickens pode muito mais importante para o entendimento do universo da classe operária inglesa do que alguns dos textos sempre recorridos nesses cursos.

${ }^{10}$ Esse é um rico filão que, no caso brasileiro, ainda tem muito a ser explorado. Ver, por exemplo, as incursões analíticas sobre a leitura brasileira de Max Weber (VILLAS-BOAS, 2001: VIANA, 2001)
} 
orbitaram em torno do socialismo estatista da ex-URSS. Trabalhando com maestria a lenda popular mongol de que os homens estão destinados a herdar as almas dos cachorros, os cineastas nos levam à comovente percepção das mudanças sociais e culturais da Mongólia apreendidas pelo espírito de Basaar, um cão vadio de Ulan Bator, logo após o momento de sua morte. Na retrospectiva da vida de Basaar, emergem as paisagens sociais de um país no qual a economia de mercado progressivamente vai destruindo aquilo que o totalitarismo soviético não conseguiu: os laços de solidariedade e de pertencimento atrelados ao ethos budista.

$O$ Estado de Cão é uma sedutora aula de antropologia. Tanto o filme quanto a trajetória de um dos seus diretores, o belga Peter Brosens, nos fornecem importantes pistas para uma reflexão sobre a necessidade de incorporar novas linguagens no ensino de Ciências Sociais. Brosens, formado em geografia e antropologia, tem transformado o seu trabalho como cineasta numa expressiva aventura etnográfica (que se traduz em filmes e documentários filmados na Mongólia e no Equador). Ao seguir essa trajetória, lembra-nos a importância de (re)pensarmos as formas de comunicação das nossas interpretações de mundo. Para o curso de Ciências Sociais, a incorporação de linguagens como a do cinema (sem excluir a literatura, a música, a televisão e todas as novas TI\&C) dá um novo sentido à noção de formação. Esta passa a ser pensada, resgatando, aliás, um dos traços constitutivos das ciências humanas no passado, como um espaço que permitiria não só a penetração numa comunidade de conhecimento (e de aquisição das "ferramentas" necessárias para pertencer a tal comunidade), mas também uma consistente "formação cultural". Ao mesmo tempo, penso que esse é o melhor caminho para se criar um espaço de interação não populista com os "repertórios culturais mobilizados pelo corpo discente" (DAY, 2000).

Há, é certo, também um sentido prático na incorporação dessas linguagens num curso de Ciências Sociais. Por exemplo, um filme como Pão e Rosas (Bread and Roses), do diretor inglês Ken Loach, é, inegavelmente, um sofisticado recurso de apoio a qualquer discussão sobre o sindicalismo na sociedade informacional. Mas há uma implicação pedagógica (e, não seria exagero afirmar, epistemológica) não menos importante: ao incorporar no curso outras linguagens e formas de inter- 
pretação do mundo, cria-se, ao menos potencialmente, um espaço para um certo exercício auto-reflexivo. Esse exercício, que começa por colocar em questão as categorias impensadas que impregnam as nossas narrativas, pode muito bem avançar até o ponto em que os alunos se sintam convidados a refletir sobre como os "conceitos" que usam (ou estão entrando em contato) nada mais são do que um conjunto de esquemas interpretativos "privilegiados". E que esse privilégio corresponde a um "acidente do Ocidente" (LASH, 1997, p.187), com uma história que precisa sempre ser recontada.

\section{c) a formação técnica qualificada.}

Não há porque cristalizar, no currículo do curso de Ciências Sociais, a "tensão entre as tarefas da formação cultural e da qualificação profissional" (GARCIA, 2000, p.138) e nem porque se antever a inevitabilidade de um cenário em que um desses pólos seja totalmente contemplado e o outro esvaziado. É possível trabalhar na implementação de um projeto curricular em Ciências Sociais que possibilite ao aluno acesso não apenas ao "cânone" da área, mas também a aquisição dos instrumentais teóricos e das técnicas de ensino e pesquisa que subsidiem a sua intervenção qualificada como educador, pesquisador ou assessor de movimentos sociais e organismos públicos e privados.

A formação técnica não implica prejuízos para o projeto de produção de um discurso crítico sobre a sociedade. Ao contrário, potencializa esse exercício crítico na medida em que novas formas de percepção de interpretação do mundo são incorporadas ao curso. Isso porque se uma formação técnica qualificada pressupõe um conhecimento mínimo sobre os principais instrumentos de pesquisa social (incluindo um domínio básico de estatística e o manejo seguro de softwares como o SPSS ou aqueles produzidos no âmbito da Social Network), ela não pode prescindir de uma capacidade de leitura "extensiva" do que ocorre no vasto campo das Ciências Sociais (a leitura dos periódicos internacionais de destaque da área, por exemplo).

Para ilustrar, podemos exemplificar algumas traduções concretas dessa formação técnica: 
1) capacitação para a atuação com "tato pedagógico" no ensino médio (o que significa tanto uma compreensão razoável do universo adolescente e jovem atual - os novos processos de individualização, valores éticos emergentes, novas identidades coletivas, etc. - quanto um traquejo didático mínimo);

2) o domínio de conhecimentos que permitam a participação em equipes de elaboração e/ou avaliação de projetos de intervenção social (políticas públicas ou ações de ONGs, instituições políticas e culturais) ou em grupos de trabalho de confecção de relatórios técnicos de avaliação institucional e de impactos sócio-ambientais;

3) o manejo e a análise de bancos de dados virtuais bem como a elaboração de design de pesquisas para empresas e órgãos públicos.

\section{d) o curso como espaço para o pensamento crítico}

Um dos maiores desafios colocados para a análise social é separar o que "é" (ou, melhor, o que percebemos na realidade) daquilo que "queremos". Quando o pólo do queremos torna-se mais forte, não é raro que o espírito crítico seja subjugado e a análise social subordine-se a algum projeto ideológico. A tênue separação entre esses dois universos é alvo de um longo debate, suficientemente socializado para que não seja necessário repetir os seus termos neste texto; importante aqui é chamar a atenção para o fato de que, se as Ciências Sociais são a principal fonte do discurso crítico sobre os atores e processos sociais contidos e impulsionados pela sociedade moderna, essa crítica não se confunde com a crítica socialista aos problemas sociais do que se denomina irrefletidamente de capitalismo (muito embora incorpore muitas de suas apreensões).

O espírito crítico, num curso de Ciências Sociais, manifesta-se sobretudo no cultivo da incerteza permanente em relação às pretensões das diversas teorias de fundamentar a análise do mundo social. E isso se traduz pela não exclusão, a priori (especialmente por motivos políticos e ideológicos), de qualquer teoria do social. Se na vida cotidiana comum, diz-nos Agnes Heller (1989, p.72) a busca da compreensão faz- 
nos conscientes de quão opaco e insondável é o mundo, por que o mesmo não haveria de ocorrer com as Ciências Sociais? Elas

"prometem a iluminação do incompreensível e do opaco, prometem dotar de auto-conhecimento a sociedade moderna, entretanto, adentram no mesmo caminho em espiral no qual entram os atores cotidianos ao questionar suas formas de compreensão tradicionais."

Assim, cultivando uma postura pluralista, talvez se possa tornar factível a tarefa de uma teoria crítica que é, como apontou Karl Marx em uma carta de 1843 a Arnold Ruge, o "auto-aclaramento das lutas e desejos de uma época". Essa posição, ao contrário das interpretações simplistas, não legitima uma certa "ciência social militante" que viceja em alguns de nossos cursos e que, não raro, ajuda a mistificar tanto o tratamento de alguns temas (processos eleitorais, processamento institucional de demandas, pobreza e indicadores sociais sob o capitalismo, por exemplo) quanto alguns atores sociais (gangs, lésbicas, movimentos negros, etc.). No primeiro caso, a crítica é confundida com uma narrativa negativista; no segundo, com louvação panfletária.

Neste último caso situam-se as louvações acadêmicas ao MST nos cursos de Ciências Sociais. Esse ator político se transformou- em personagem chave da "baderna interpretativa"17 a qual se reduziu a análise sociológica da lutas no campo e da questão agrária brasileira no início do século XXI. O MST analisado pela ciência social militante, com raras exceções, "aclara" muito pouco não apenas o que ocorre no mundo rural quanto as formas de sociabilidade que ocorrem no interior desse "movimento"18 , para não falar das "consequiências não-intencionais" da sua entrada em cena. Não deixa de ser melancólico perceber que a história repete-se, agora como farsa, e muitas das pessoas que dizem fazer uma ciência social crítica no Brasil contemporâneo pros-

17 Feliz expressão cunhada por Martins (2000, p. 98).

18 "O MST é um movimento social ou uma organização formal de representação de interesses? Correndo o risco de adentrar interminável controvérsia, sustentaria que o Movimento é, atualmente, na maior parte do Brasil, mais uma organização política em seu estrito sentido e, menos (muito menos, em vários estados), um movimento social, como a literatura usualmente nos indicaria" (NAVARRO, 2001). 
tram-se a-criticamente diante do MST tal qual parte da esquerda comunista ocidental ${ }^{19}$ portava-se diante do chamado "socialismo realmente existente" há não mais do que três décadas.

Só o distanciamento da "ciência social militante" pode contribuir para "aclarar" a análise sociológica dos atores sociais concretos (que, como todos nós humanos, são embebidos em contradição e imprevisibilidade). A abertura crítica das Ciências Sociais significa a superação dos preconceitos políticos em relação a determinadas teorias ou modelos de compreensão do mundo social pelo fato das mesmas não se enquadrarem nos figurinos do que seria uma "interpretação crítica" (confundida com interpretação "de esquerda"). Na realidade, como aponta Michael Stopper (2001), o grande progresso das Ciências Sociais nos últimos anos não correspondeu exatamente a um avanço das teorias radicais, mas a um sofisticado movimento teórico patrocinado por filões teóricos como a public choice ou a "nova sociologia econômica" e o estudo de temas como "mercados imperfeitos", "direitos de propriedade", "interpretação cultural" e "estrutura corporativa", dentre outras teorias e abordagens, que não podem ser identificadas como alinhadas à esquerda, no espectro político e acadêmico.

Possibilitar o acesso a um arsenal teórico como o anteriormente citado potencializa a reflexão crítica dos alunos. Aliada a uma postura docente de estímulo à produção de textos pelos alunos, poder-se-ia contribuir para uma alteração no perfil intelectual do nosso corpo discente. Hoje, quando a análise crítica é, muitas vezes, assimilada a discurso panfletário ou a louvação pouco crítica dos movimentos sociais, criam-se as condições para que um determinado tipo de aluno, o "sabichão", muito comum também em cursos de pós-graduação, tome conta das salas de aula dos cursos de Ciências Sociais. Paulo Ghiraldelli Ji. (2001) afirma que esse tipo de aluno, geralmente oriundo de alguma militância partidária, compromete o andamento de qualquer aula mini-

${ }^{19}$ Com as louváveis exceções de grupos como o francês Socialismo ou Barbúric e. já no final do pesadelo, dos intelectuais ligados ao antigo Partido Comunista Italiano (PCI). Seria injusto não fazer referência também às denuncias dos atores políticos ligados ao trotskismo, mas estes, em boa parte prisioneiros dos esquematismos anti-democráticos do leninismo, estiveram. desde o começo. epistemologicamente desarmados para uma crítica radical ao fenômeno totalitário. 
mamente elaborada. Muito comum em espaços nos quais a cultura oral se sobrepõe a cultura escrita, o aluno "sabichão" não faz questões, mas "intervenções" ou "colocações".

A criação de uma cultura acadêmica de valorização do curso como um espaço para a reflexão crítica não será produto da boa vontade de professores e alunos. É necessário, também nesse tópico, a construção de um projeto que dê suporte a essa cultura crítica. E já existem experiências que podem ser tomadas como referências. Os grupos PETs, por exemplo, têm se constituído em importantes espaços para a iniciação científica, o treinamento para pesquisa, o exercício da escrita e o contato com as diversas correntes e escolas do campo de saber no qual se insere o curso. Embora o PET venha sendo gradativamente esvaziado pelo MEC, os ganhos da sua experiência podem ser socializados e servir de inspiração para outros grupos (formados por alunos e professores) que poderiam se constituir de forma autônoma em cada Departamento Acadêmico.

\section{e) o espaço dos saberes nômades}

No processo de disputa por legitimidade social para as suas linguagens e modos de escrever sobre sociedades e culturas, as Ciências Sociais instituem identidades individuais e coletivas em torno de mapas cognitivos que denominamos "disciplinas". Modos de perceber o mundo moderno, as disciplinas contribuem para "aclarar" o nosso mundo e possibilitam a atribuição de sentido ao que parece "ter sentido" (HELLER, 1989, p.73), mas, ao estabelecer fronteiras, as disciplinas também limitam percepções e inibem a colocação de problemas. Tomando essas fronteiras como fetiches, não é raro que se esqueça algo que é fundamental ser apropriado pelos que adentram no universo das Ciências Sociais: os autores clássicos e os mais importantes cientistas sociais da atualidade quase sempre desconsideraram as disciplinas como referências para suas incursões analíticas.

Esse aprisionamento disciplinar se traduz, não raro, numa limitação à ousadia intelectual. Como corolário, emerge o conformismo com os esquemas interpretativos de cada disciplina. Quantos escritos insossos e aulas destituídas de paixão têm sido produzidos para atender 
aos ditames do bom comportamento disciplinar! Situação dolorosa porque ajuda a fabricar homens e mulheres "partidos" num espaço que deveria ser o da reflexão e da ousadia. Não é raro, por exemplo, que aquele bom professor de ciência política, competente na interpretação de $O$ Príncipe, seja também um leitor voraz de Ítalo Calvino. No batepapo informal, entusiasma com seus comentários criativos sobre as obras do grande escritor italiano do século XX. Entretanto, em suas aulas ou em seus artigos, jamais se permitirá cotejar $O$ Príncipe com Palomar. Pode até encontrar os nexos, perceber a riqueza dos contrapontos, as imensas possibilidades de significação, mas não se permite essa ousadia. Sabe o preço que teria que pagar! Não deixa de ser triste perceber quantas possibilidades de enriquecimento cultural de nosso ambiente acadêmico são perdidas e chaves de leituras são fechadas porque, aprisionados pelas culturas disciplinares, esquecemos o fato de que é parte constitutiva da condição humana

"jamais sufocar em si a necessidade de traduzir, de passar de uma linguagem a outra, de uma figura concreta a palavras abstratas, de símbolos abstratos a experiências concretas, de tecer e tornar a tecer uma rede de analogias. Não interpretar é impossível, como é impossível abster-se de pensar" (CALVINO, 1994, p.90).

Paradoxalmente, nunca se falou tanto de interdisciplinaridade quanto nos últimos anos. De fato, projetos de pesquisa e cursos de pós-graduação ditos interdisciplinares pulularam no Brasil dos últimos anos. E não são poucas as discussões sobre as trilhas e atalhos para a construção da interdisciplinaridade. Entretanto, como já apontava há mais de duas décadas Clifford Geetz, muito dessa discussão está condenada à esterilidade, na medida em que se busca construir campos interdisciplinares com as mesmas linguagens das disciplinas (GEERTZ, 1980). Em outras palavras, os nossos estudos interdisciplinares ainda não conseguiram romper com a ontologia e epistemologia disciplinares e instituir campos relacionais trans-disciplinares.

Obviamente, a fossilizada estrutura universitária brasileira, que, não raro, desestimula até mesmo as experiências interdisciplinares, é um grande obstáculo ao "esquecimento das disciplinas" (SAWYER, 2000). 
Entretanto, as diretrizes curriculares do curso de Ciências Sociais legitimam experiências que, horizontalmente, devem ser tentadas, mesmo enfrentando a rigidez da estrutura acadêmica ${ }^{20}$. No que diz respeito ao ensino, por exemplo, dever-se-ia estimular a oferta de cursos trabalhados conjuntamente por docentes oriundos de campos disciplinares diversos (e não apenas das Ciências Sociais).

Na estrutura da graduação em Ciências Sociais, os cursos transdisciplinares poderiam ocupar parte considerável da segunda metade da grande grade curricular (após a oferta das tais "disciplinas obrigatórias"). Temáticas transversais, que potencializassem os espaços de diálogos já existentes (estudos urbanos, estudos de gênero, questão agrária, políticas públicas, sociedade e meio ambiente, etc.), poderiam ser transformadas em disciplinas optativas e ofertadas semestralmente. A esse primeiro passo, seguir-se-iam projetos mais ousados (e academicamente mais difíceis de implementar), como a oferta de cursos que envolvessem, desde a elaboração até a execução, docentes de diversos departamentos acadêmicos (e, consequientemente, de distintas disciplinas). Poderíamos, por exemplo, ter um sociólogo e um historiador da arte trabalhando uma temática como o movimento sindical no cinema. Ou um curso sobre pensamento social brasileiro centrado no universo de Machado de Assis ${ }^{21}$, envolvendo um sociólogo, um politólogo e um especialista em literatura brasileira.

Esse o caminho para a (re)configuração do curso de Ciências Sociais: a sua metamorfose em um espaço de "saberes nômades" (DUMAS, 1999). Uma espécie de "espaço liminar"22, momento de transição

** No caso da UEL, a estrutura seriada dos cursos é um obstáculo quase intransponível para a construção de uma estrutura curricular aberta, pluralista e trans-disciplinar.

2 Rezende (2000) aponta para a necessidade de explorar esse rico filão teórico. Trata-se de um campo temático que tem merecido também sofisticadas incursões como aquelas feitas por Roberto Schwarz.(1992).

22 O conceito de espaço liminar, como se pode apreender das leituras de clássicos da antropologia como Arnold Van Gennep e Victor Turner, busca "expressar um situação intersticial. Na liminaridade, perde-se a posição anterior (adolescente, solteiro) e adentra-se numa nova posição social, conquistada pela ultrapassagem do espaço de iniciação" (LOPES JR, 2001, p. 67). Una boa amostra da utilização desse conceito em estudos sobre globalização e dinâmica cultural encontra-se nos trabalhos da socióloga norte-americana Sharon Zukin (1991). Uma referência mais atual encontra-se na ótima discussão empreendida por DaMatta (2000). 
entre uma identidade cristalizada (disciplinar) e a abertura para o contingente, o indeterminado e pluralidade (trans-disciplinar). Essa é uma perspectiva que intimida e causa medo. Não poucas pessoas preferirão a segurança e o "calor do lar" das disciplinas à insegurança ontológica do nomadismo. Por isso, a trans-disciplinaridade não é possível sem uma certa "coragem do abandono" (GIRI, 2002, p. 112) e uma disposição para mover-se em terras estrangeiras. Implica, portanto, os mesmos riscos e promessas de aventuras da imigração.

Indeterminado e relacional, o espaço trans-disciplinar alimentase não só de curiosidades e ousadias intelectuais, mas também de virtudes como o reconhecimento do outro, a humildade e a generosidade ${ }^{23}$. É, como a imigração analisada no majestoso ensaio de Octavio Ianni (1999) sobre o filme Rocco e seus irmãos, também uma "insondável travessia." Mas sem emigrar epistemologicamente, e ancorados no lugar disciplinar fornecido pela tradição, a atividade pedagógica nos cursos de Ciências Sociais condena-se à monótona repetição do já feito.

\section{Conclusão}

A oficialização pelo MEC das Diretrizes Curriculares da graduação em Ciências Sociais e a redefinição da carga horária das licenciaturas pelo CNE reforçam a necessidade de uma reforma ampla na estrutura curricular dos cursos. Essa reforma curricular não pode ser concebida como uma tarefa técnico-burocrática, um mero exercício de engenharia institucional centrado, não raro, nas discussões sobre o ementário das

${ }^{23}$ Essas virtudes necessárias à transdisciplinaridade são ressaltadas no formidável artigo do cientista social indiano Ananta Kumar Giri. já citado, que toma como referência, para a elaboração de suas proposições, os últimos escritos do filósofo Alasdar MacIntyre. Quem conhece a história de futricas, piadas infames e exercícios rasteiros de desqualificação de trabalhos de colegas em certos ambientes acadêmicos de nossas universidades sabe muito bem o quanto o cultivo dessas virtudes é fundamental. Não que os espíritos embrutecidos irão deixar de (des)qualificar o trabalho alheio a partir de suas pobres balizas sobre o que entendem ser "sério", mas, aos poucos, incorporando-se esses valores e virtudes. criar-se-á um ambiente em que essas tristes pessoas deixarão de atormentar, com as suas verdades perfeitas, as salas de aulas e terão sua audiência reduzida aos seus terapeutas. 
disciplinas e na distribuição da carga horária das mesmas. A proposta que esbocei acima, aponta para a necessidade de encarar a reforma curricular nos cursos de Ciências Sociais como um momento para aprofundar as discussões sobre o sentido mesmo da oferta do curso no universo acadêmico brasileiro do início do século XXI. Trata-se de incorporar, nas discussões sobre os nossos cursos, as mesmas constatações que alguns dos mais eminentes cientistas sociais de nosso tempo apreendem como elemento característico de uma sociedade "destradicionalizada": a idéia de que a expansão da reflexividade social exige uma permanente justificação das posturas e projetos tanto dos indivíduos quanto das instituições sociais. Em outras palavras, a oferta dos cur'sos de Ciências Sociais, que defendo deva continuar ocorrendo, deve estar alicerçada num consistente projeto político e pedagógico.

A elaboração desse projeto não é uma tarefa exclusiva de um gxupo, mas responsabilidade dos diversos atores do curso. Nesse sentido, a criação de instrumentos e espaços que possibilitem a emergência das percepções e demandas do corpo discente é uma precondição para o avanço do próprio processo de reformulação do currículo. Essa proposição, que não pode ser confundida com populismo acadêmico, expressa a compreensão de que o êxito de qualquer processo pedagógico na Universidade contemporânea está diretamente relacionado à apreensão do universo social e dos repertórios culturais mobilizados pelos jovens.

A.ssim concebida, a reforma curricular de um curso de Ciências Sociais não pode contornar a discussão sobre as linguagens atualmente utilizadas e aquelas que necessitam ser incorporadas. Deixando claro que não se trata apenas de procurar meios para tornar mais competente a transmissão de "mensagens". O desafio é bem outro: trata-se de criar as condições para o surgimento de uma prática pedagógica que, ao mesmo tempo em que se preocupa em possibilitar a aquisição de competências e habilidades técnicas, não deixa de se perceber como momento de formação cultural ${ }^{2+}$.

Na medida em que o curso de Ciências Sociais seja entendido também como um projeto de formação cultural, redefine-se os tristes

\footnotetext{
Sigo açui uma instigante percepção apontada por Klaassen (2002), a partir de uma pesquisa de campo em escolas.
} 
cenários em que cursos - ou disciplinas - são subjugados pelos discursos e práticas militantes. Na medida em que se entenda que essa formação se alicerça na pluralidade, na flexibilização das fronteiras disciplinares e na interlocução substantiva entre docentes e discentes, um outro elemento é introduzido como destaque na pauta de discussões da reforma curricular: quais as práticas pedagógicas ${ }^{25}$ que devem guiar a vida acadêmica de um curso de Ciências Sociais.

Tomando uma metáfora emprestada de um artigo de Charles Tilly, assumi que o curso de Ciências Sociais deve ser entendido com um lago. Guiado por essa compreensão "ecológica", procurei tanto responder a questões como, por exemplo, o lugar da licenciatura no curso quanto apontar algumas direções (ou vertentes) que deveriam alimentar uma graduação em Ciências Sociais na atualidade. Por outro lado, essa metáfora também nos indica que o estudo da redefinição curricular do curso poderia assumir os contornos que a limnologia deu aos estudos dos corpos de águas continentais: um campo de investigação, onde os saberes e práticas oriundas das mais diversas disciplinas centram-se na compreensão dos singulares ecossistemas formados pelos lagos.

1 Entendo que a prática pedagógica não diz respeito apenas aos recursos didáticos ou às formas de interação entre educandos e educadores, mas também ao conjunto de esquemas irrefletidos de interpretação do mundo e de posturas de relacionamento interpessoais que modelam as relações no espaço educacional. Nesse sentido, a prática pedagógica nada mais é do que uma "prática cultural" (GIROUX, 2000). 


\section{Referências Bibliográficas}

ADORNO, Sérgio. Os aprendizes do poder: o bacharelismo na Política Liberal. São Paulo: Paz e Terra, 1988.

ALEXANDER, Jeffrey C. A importância dos clássicos. In: GIDDENS, Anthony; TURNER, Jonathan (Orgs.). Teoria Social Hoje. São Paulo: UNESP, 1999.

BARRERE. Anne: MARTUCCELLI, Danilo. A escola entre a agonia moral e a renovação ética. Educação \& Sociedade, v.22, n.76, p.258-277, 2001.

BERMAN. Marshall. Tudo que é sólido desmancha no ar: a aventura da modernidade. São Paulo: Companhia das Letras, 1986.

BOURDIEU, Pierre. A Reprodução: elementos para uma teoria do sistema de ensino. Rio de Janeiro: Francisco Alves, 1975.

O Poder Simbólico. Rio de Janeiro: Difel, 1989.

BRASIL. Parecer CNE/CP 009/2001. Diretrizes Curriculares Nacionais para a Formação de Professores da Educação Básica, em nível superior; curso de licenciatura. de graduação plena. Disponível no site: <http://www.mec.gov.br>. Acesso em: jul. 2001a.

BRASIL. Parecer N. ${ }^{\circ}$ CNE/CP 28/2001. Dá nova redação ao Parecer CNE/CP 2II 2001, que estabelece a duração e a carga horária dos cursos de Formação de Professores da Educação Básica, em nível superior; curso de licenciatura, de graduação plena. Disponível no site: <http://www.mec.gov.br>. Acesso em: julho de $200 \mathrm{lb}$.

CALVINO, Ítalo. Palomar: São Paulo: Companhia das Letras, 1994.

CASTELlS. Manuel. A sociedade em rede. São Paulo: Paz e Terra, 1999a. O poder da identidade. São Paulo: Paz e Terra, 1999b.

CLIFFORD. James. Las culturas del viaje. Revista de Occidente, n.160, p. 45-74, 1995.

DAMATTA. Roberto. Individualidade e liminaridade: considerações sobre os ritos de passagem e a modernidade. Mana: Estudos de Antropologia Social, v.6, n.1, p07-29, 2000 .

DAY, Christopher. Teachers in the Twenty-first century: time to renew the vision. Teachers and Teaching: theory and practice, v.6, n.1, p101-115, 2000.

DUMAS, Brigitte. Les savoirs nômades. Sociologies et Sociétés, v.31, n.1, p.5162.1999 . 
FEATHERSTONE, Mike. O Desmanche da Cultura: globalização, pós-modernismo e identidade. São Paulo: Studio Nobel, 1997.

FIÚZA, Guilherme. PHD em panfletagem. Disponível em: <http://www.no.com.br $>$. Acesso em: dez. 2001.

FRANCO, Augusto de. Uma guerra contra a democracia: as consequiencias do 'Estado de Guerra' instaurado pela campanha americana contra o terrorismo. Disponível em: $1<$ http://www.no.com.br>. Acesso em: dez. 2001.

GARCIA, Sylvia Gemignani. A questão da universidade e da formação em ciências sociais. Tempo Social, v.12, n.1, p.123-140, 2000.

GEERTZ, Clifford. Blurred genres: refiguration of social thought. American Scholar; v.49, p.165-179, 1980.

GHIRALDELli Jr., Paulo. Treze "Teses" Sobre a Pós-graduação no Brasil em Filosofia, Ciências Sociais e Educaf̧ão. Disponível em: <http://www.pauloghiraldelli.pro.br>. Acesso em: nov. 2001.

GIDDENS, Anthony. Sociologia: uma breve porém crítica introdução. Rio de Janeiro: Zahar, 1984.

As consequiências da modemidade. São Paulo: UNESP. 1993.

GIRI, Ananta Kumar. The calling of a creative transdisciplinarity. Futures, v. 34. n.1, p.103-115, 2002.

GIROUX, Henry. Slacking Off: Border Youth and Postmodern Educatio. Disponível em: <http://www.gseis.ucla.edu/>. Acesso em: jul. 2000.

HARVEY, David. Condição Pós-moderna. São Paulo: Loyola. 1993.

HELLER, Agnes. De la hermenéutica en las ciencias sociales a la hermenéutica de las ciencias sociales. IN: HÉLLER, Agnes ; FEHÉR. Ferenc. Politicas de la postmodernidad: ensayos de critica cultural. Barcelona: Península, 1989.

IANNI, Octavio. Insondável Travessia (Rocco e seus irmãos). Lua Nova, n.48. p.233-238, 1999.

INTRODUCTION-The fragmentation of sociology. Joumal of Classical Sociology: v.1, p.05-12, 2001 .

KLAASSEN, Cess A. Teacher pedagogical competence and sensibility. Teachers and Teaching: theory and practice, v.18, n.1, p.151-158, 2002.

KRITSCH, Raquel. Maquiavel e a construção da política. Lua Nova, n.53, p.181190, 2001. 
KOUTSELINI. Mary. Contemporary Trends and Perspectives of the Curricula: towards a meta-modern paradigm for curriculum. Curriculum Studies, v.5, n.1, p.87-101, 1997.

LASH. Scott. A reflexividade e seus duplos. In: GIDDENS, Anthony, BECK, Ulrich; LASH. Scott. Modemização reflexiva. São Paulo: UNESP, 1997.

LENARDÃO, Elsio. Violência como desvio social. Mediações, v.5, n.2, p.185$210,2000$.

LEIS. Hector Ricardo. A tristeza de ser sociólogo no século XXI. Dados, v.1, n.4, p. $737-760,2000$.

LOPES Ji.. Edmilson. A construção social da cidade do prazer: Natal. Natal: EDUFRN, 2001.

MARTINS, José de Souza. Reforma Agrária: o impossível diálogo sobre a História possivel. Tempo Social, v.11, n.2, p.97-128, 2000.

MASSEY, Doreen ; JESS, Pat (Orgs.). A place in the world? New York: Oxford University Press, 1995.

MENEN, Max. Van. On the epistemology of reflective practice. Teachers and Teaching: theory and practice. v.1, n.1, p.33-50, 1995.

The pathic principle of pedagogical language. Teachers and Teaching: theory and practice, v.18, n.1, p.215-224, 2002.

MICELI. Sergio (Org.). O que ler na ciência social brasileira: antropologia. São Paulo: Sumaré, 1999a.

Sumaré. 1999b.

O que ler na ciência social brasileira: sociologia. São Paulo:

O que ler na ciência social brasileira: política. São Paulo:

Sumaré, 1999c.

MORENO. Montserrat. Como se ensina a ser menina: o sexismo na escola. Campinas: UNICAMP, 1999.

NAVARRO, Zander. MST: decifrar é preciso. Disponível no site: <http:// cevep.ufing.br/bacp>. Acesso em: jul. 2001.

POLANYI, Karl. A Grande Transformação. Rio de Janeiro: Campus, 1980.

REIS. Elisa P. As ciências sociais e o bug do milênio. RBCS, v. 14, n. 39, p. 05-11, 1999.

REZENDE, Lucinéa A. de; BALTAR, Ronaldo. Ensino e pesquisa: uma proposta para o curso de Ciências Sociais. Mediações, v.5, n.1, p.147-156, 2000. 
REZENDE, Maria José de. Mudança social no Brasil: a construção de un ideário conservador. Tempo Social, v.10, n.2, p.159-189, 1998.

A cultura política brasileira na obra de Machado de Assis. Boletim Centro de Letras e Ciências Humanas, Londrina. n.39, p. 79-94. 2000.

SAWYER, Andrew. Long live postdisciplinary studies! Sociology and the curse of disciplinary parochialism/imperialism. Disponivel em: <http:// www.comp.lancaster.ac.uk/sociology/soc025as.html>. Acesso em: jul. 2000.

SCHWARZ, Roberto. Um mestre na periferia do capitalismo: Machado de Assis. São Paulo: Duas Cidades, 1992.

STORPER, Michael. The poverty of Radical Theory Today: From the False Promises of Marxismo to the Mirage of Cultural Turn. International Journal of Urban and Regional Research, v.23, n.1, p.155-179, 2001.

THOMPSON, John B. A mídia e a modernidade: uma teoria social da mídia. Petrópolis: Vozes, 2000.

TILly. Charles. La democracia es um lago. Disponível em: <http:// www.politica.com.ar>. Acesso em: maio 2000.

TOMASSINO, Kimiye; JEOLÁS, Leila Sollberg. O trote como ritual de passagem: o universal e o particular. Mediações, v.5, n.2, p.29-49, 2000.

TOMAZZI, Nelson Dácio. Sociologia da Educação. São Paulo: Atual. 1997.

VIANA, Luis Werneck. Weber e a interpretação do Brasil. Disponível em: <http:/ /www.artnet.com.br/gramsci>. Acesso em: jul. 2001.

VILLAS-BOAS,Gláucia. A recepção da sociologia alemã no Brasil. Disponível em:<http:www.ifcs.ufrj.br\%. Acesso em: jul. 2001.

ZUIN, João Carlos S. Sobre a idéia de mundo. Mediações, v.3, n.1, p.38-43. 1998.

ZUKIN, Sharon. Landscapes of Power: From Detroit to Disney World. Los Angeles: University of California Press, 1991. 


\section{Abstract}

This article is a contribution to the debate on the curriculum of the courses of social sciences in Brazil. Taking as reference the metaphor of the lake, used by Charles Tilly to think the formation of a democratic culture, we tried to think the several constituent elements of a new academic practice in the social sciences.

Key-Words: Curriculum; Pedagogic Practice; Social Sciences in Brazil; Course Project. 